mouth and one which attacks staphylococci resistant to normal penicillin. Compounds of this kind open up exciting prospects in the antibiotics field.

Other studies conducted in Rome have been on the green iron-containing streptomycete pigment ferriverdin, on submerged kojic acid and citric acid fermentations and on the production of ergot alkaloid in submerged fermentation. Among the chemical engineering aspects of chemical microbiology there have been extensive studies on agitation and aeration. Biological studies have included investigations on the relations between morphology and metabolism in filamentous fungi and genetical problems in fila. mentous fungi. Studies on carbohydrate metabolism in animals have been concerned with the mode of action of insulin and the interrelations between carbohydrate and amino-acid metabolism in brain and nervous tissues.

\title{
DIRECTION OF SCIENTIFIC AND TECHNICAL RESEARCH IN FRANCE
}

\begin{abstract}
A
PUBLICATION, French Science News (2, April-June, 1959), published by the Direction Générale des Affaires Culturelles et Techniques for the Ministère des Affaires Étrangères, describes the organization which has been set up to determine policy for scientific and technical research throughout the country. Two high-ranking committees have been formed, the first being an Interministerial Committee, the members of which include the Prime Minister as chairman, the Minister of National Education, the Minister of the Armies, the Minister of Finance and Economic Affairs, the Minister of Industry and Commerce, the Minister of Agriculture, the Minister of Public Health, and qualified representatives of the French community.

The main tasks of the Interministerial Committee, which is responsible for proposing to the Government all measures for the development of scientific and technical research, are as follows :

"To maintain a fair balance between the amount of credits appropriated for the different fields of research ;

"To develop to its maximum usefulness French national research, which presupposes a detailed study of the profession of a research specialist and the milieu in which research is performed;

"To anticipate new research possibilities which will benefit the nation, which presupposes long-
\end{abstract}

term government options in the field of science."

The second is an Advisory Committee, the members of which are: Maurice Letort as chairman (Letort is scientific director of Research and Studies, Centre of Charbonnages de France); Prof. Pierre Aigrain. vice-president of the Paris Faculty of Science; Prof. Jean Bernard, Paris Faculty of Medicine; Prof. Rene Dumont, National Agronomic Institute; Prof. Paul Germain, Paris Faculty of Science; Rene Latarjet, co-director of the Radium Institute and the Curie Foundation; Prof. Andre Lichnerowicz, Collège de France; Maurice Ponte, general director of the Compagnie Générale de T.S.F.; Prof. Charles Sadron, Strasbourg Faculty of Science and director of the Centre of Macromolecular Research; Pierre Taranger, industrial director of the French Atomic Energy Commission; and Felix Trombe, research director at the National Scientific Research Centre (Mont-Louis).

The Committees are served by a common secretariat directed by a general delegate. The general delegate can form work committees for specific objects and composed of experts. He works in close co-operation with the general planning commissioner.

The journal is published quarterly by the Association pour la Diffusion de la Pensée Francaise, 23, rue La Perouse, Paris, $16^{\mathrm{e}}$.

\section{PRODUCTION AND CONSUMPTION OF ENERGY IN GREAT BRITAIN}

\begin{abstract}
$\mathrm{D}^{2}$ URING the past four years some remarkable changes have taken place in the consumption of energy in the United Kingdom. Indeed, since the War the situation in the whole of Western Europe has changed, from that of an energy-exporting economy to that of an energy-importing one. A few years ago there were fears of a shortage of energy in Great Britain. To-day there is the picture of rapidly rising coal stocks, and of real alarm in the mining villages.

Recently this subject was dealt with in an enlightening talk to the Fuel Luncheon Club by Sir Harold Hartley*, whose association with the international study of the energy problems of Western Europe entitle him to be listened to with earnest attention.

* Talk to the Fuel Luncheon Club on January 19 on "Energy in * Talk to the Fuel Luncheon Club on January 19 on "Energy in
the United Kingdon-the Changing Scene", by Sir Harold Hartley.
\end{abstract}

His revelations should disturb any complacency with regard to the extent of our technological effort in the development of our coal resources.

The pattern of the energy consumption has changed quickly in the following respects in the past four years. Coal consumption fell 3 per cent per annum between 1955 and 1959 , while that of oil rose by 12 per cent per annum. Electrieity consumption continued its steady annual rise of 6 per cent, while gas declined by 1 per cent per annum. The competitive position depends upon factors of efficiency and of convenience, the relative basic prices of the therm in the primary forms of energy being : coal at the pithead, price $3 \frac{1}{2} d$., at $£ 10$ per ton, $8 \frac{1}{2} d$.; fuel oil, at $£ 10$ per ton, $6 d$.; paraffin, at $£ 20$ per ton. $11 d$.; while gas at the average price costs $1 s .9 d$. per therm, and electricity at $1 \cdot 55 d$. per unit, $3 s .9 d$. 
While stagnant demand has struck the coal-fields, technical advancement has raised the potential productivity of the deep mines to a figure of 3.86 tons per man-shift. This is a pointer to the possibilities of saving the competitive position of coal so far as regards price. The technological aspects offer greater possibilities, if adequately pursued. Thus, in the production of electricity the coal station can compete favourably with the nuclear energy station, because of the greater inherent efficiency that has been developed over recent decades through improvements in technique and design.

The same story of change and advancement could apply to the gas industry, since the technical outlook of the industry has changed radically. It is not likely that the gas industry will build in the future conventional carbonizing plants, for attention is now being turned towards the total gasification of coal, bringing into use new techniques applicable to the use of cheaper low-rank coals. With these there may well be combined processes involving the gasification of oil, and the use of imported liquid methane. With high-pressure gas generation, pipe-line distribution over long distances becomes practicable and economic.

In regard to oil, the question of availability has been changed by the outlook regarding the discovery of new sources of oil in the Middle East, Libya and the Sahara, and of large natural gas fields in the Pyrenees. Against this must be set the likely growth of demand for energy, as the under-developed countries in the world respond to modern standards of living.

Sir Harold Hartley, in considering the energy outlook, has attempted to sketch the future pattern of energy consumption in Britain. Some 280 million tons of coal equivalent will be required per annum by 1965 . Of this, some $9 \frac{1}{2}$ million tons may come from nuclear energy, and 8 million tons in coal equivalents from hydro-electricity, coke and oil for generating power, leaving some 55 million tons per annum for steam generation by coal, an increase of some 10 million tons over 1959. The true forecast for the growth of other uses of coal, gas and oil offers a more difficult problem, and may well depend upon the pattern of technological advancement. Gas, provided it can bo made at a competitive price, has potentialities in the domestic and industrial sphere, at three different levels of calorific value : a domestic gas at 500 or more B.T.U./cu. ft.; a synthesis or industrial gas of 320 B.T.U.; and a producer gas of 180 B.T.U./cu. ft., for which there are still uses, particularly in specialized fields and where the gas can be used, as in coke production, to free fuels of higher calorific value.

The competitive power of coal and its derived fuels can only be enhanced if the needed technological effort is put into the attempts to develop the new processes needed. Inevitably, the future demand will tend towards requiring energy either through a wire or a pipe, with any question of handling refuse or polluting the atmosphere excluded. Further, in the direction of the total gasification of coal lies the only hope of solving the problem of sulphur pollution.

In the matter of these potential fields of development an adequate tempo of research and development has been sadly lacking. Sir Harold voices the opinion that national policy in regard to research and development in the field of energy is badly out of balance. Very large sums of money and much available scientific effort are devoted to the nuclear field and insufficient of these resources to the utilization of coal, our greatest national asset.

R. J. SARJANT

\section{HOST INFLUENCE ON PARASITE PHYSIOLOGY}

T HE sixteenth annual conference sponsored by the Bureau of Biological Research was held at Rutgers University, New Brunswick New Jersey, during January 29-30. The subject for discussion was host influence on parasite physiology.

The chair was occupied in turn by Dr. L. A. Stauber (Rutgers University), Dr. Norman Stoll (Rockefeller Institute) and Dr. Wm. Trager (Rockefeller Institute).

In his opening remarks, Dr. T. von Brand (Bethesda) observed that there was a time not very far back when a person interested in parasite physiology was regarded as an oddity. Now a "physiological bandwagon' was emerging, possibly a reflexion of the brilliant advances being made in biochemistry. The study of parasite physiology, he considered, had changed in many ways; more people were interested and there was an emphasis on instrumentation, which demanded complicated apparatus, although man himself was the chief factor in any research. $\mathrm{He}$ recalled that during his youth in Germany, Weinland, that prince of experimenters, had been held up in his work on Ascaris metabolism for lack of a reducing valve. Distinct differences were apparent on the lines along which research on free-living invertebrates and parasites had developed. With the former the most significant advances were made by von Friseh in the field of sensory physiology. The study of parasites had developed along more chemical lines, possibly due to the fact that such early workers as Bunge and Weinland were interested primarily in chemical reactions. The biochemistry and physiology of parasites were initiated and extended in seeking to elucidate the mode of action of old or in the search for new drugs. Advances in our knowledge of host-parasite relationships followed. Non-biochemical studies of parasites were, however, of equal importance.

Dr. L. R. Cleveland (University of Georgia) then gave a paper on the effects of insect hormones on the protozoa of Cryptocercus and termites. This woodfeeding cockroach Cryptocercus has nine families, fourteen genera, and more than thirty species of flagellate parasites in its hind-gut. During each moulting period of a host all these species undergo sexual cycles. In the flagellates of adults and inter. moult nymphal hosts, sexuality never occurs under natural conditions; when the insect growth and differentiation hormone, ecdysone, is injected into such hosts, gametogenesis is induced in their flagellates, and the time required for induction depends, within certain limits, on the amount of ecdysone injected. In an adult, 2,000 units will induce it in four genera within $3 \mathrm{hr}$.; 100 units will do the same in a 4 th instar intermoult nymph. 